\title{
Governing structural changes and sustainability through (new) institutions and organizations
}

\author{
Nathalie Lazaric ${ }^{1,2} \cdot$ Pasquale Tridico $^{3} \cdot$ Sebastiano Fadda $^{3}$
}

Received: 23 October 2020 / Revised: 23 October 2020 / Accepted: 27 October 2020 / Published online: 30 October 2020

C) Springer-Verlag GmbH Germany, part of Springer Nature 2020

"The important thing for Government is not to do things which individuals are doing already, and to do them a little better or a little worse; but to do those things which at present are not done at all." John M. Keynes (1926).

This Special Issue includes a collection of articles on structural change and the potential danger of a new age of capitalism which is being shaped by several and different fields such as financialization and roboticization, combined with jobless growth and low levels of productivity growth in the services sector, and the need to integrate sustainability issues at the supply and demand levels. This Special Issue proposes and investigates the institutions and types of governance that might be used to regulate these changes, and the risks and opportunities that are reshaping ways of doing things. The aim is to encourage cross-fertilization of the thinking related to diverse areas such as innovation, path dependency, trajectories, demand issues, and post Keynesian insights. There are several prior works in this direction (Dosi et al. 2010, 2019) which provide a "roadmap" and respond to calls for a new European industrial policy to address the nature of the structural challenges involved with a focus on instruments (Mazzucato et al. 2015).

First, we need to clarify how we understand structural change and sustainability. Structural change can be defined as the continuous introduction of new products and new production technologies involving dematerialization and energy efficiency (Ayres and van den Bergh 2005: 116). We should point out also that we do not observe a single structural change but rather diverse sources of structural changes in a range of domains including consumption, technology, production techniques, and inputs, and

Nathalie Lazaric

nathalie.lazaric@gredeg.cnrs.fr

1 Université Côte d'Azur, CNRS, GREDEG, Valbonne, France

2 University of Gothenburg, School of Business, Economics and Law, Gothenburg, Sweden

3 Università Roma Tre, Roma, Italy 
show the different aspects of structural change at the macro and meso levels (Ciarli and Savona 2019; Savona and Ciarli 2019). In a recent survey, Savona and Ciarli (2019) reviewed different aspects of structural change which have a direct impact on environmental sustainability, and the supply and demand sides. They refer to four dimensions of structural change: (1) the sectoral composition of the economy and the move from manufacturing to services or tertiarization; (2) the international division of labor and the impact on countries of changes to global value chains (GVCs); (3) technical change and the opportunities for ecological innovations and cleaner products and services; and (4) demand changes which affect consumption patterns and consumer preferences (Savona and Ciarli 2019: 247). The authors emphasize areas that interrelate with these dynamics such as the changes to GVCs which affect the division of labor, emissions, energy use, and the environmental impacts of global trade. We would add a fifth and a sixth dimension. The fifth we would suggest is related to the impact of technological breakthroughs that are accompanying the digital transformation of industry or Industry 4.0 (Cézanne et al. 2020), and the effect on the international division of labor and employment within Europe and between Europe and the rest of the world (Dachs et al. 2019; Szalavetz 2019). Finally, we suggest that the sixth dimension is related to a longer-term trend towards financialization of the economy which is accelerating structural change and its outcomes on various economies and requires closer scrutiny to obtain a truly international view of these dynamics.

Since the beginning of the 1990s, many of the advanced economies have experienced significant changes to their productive structures, and a decline in the share of manufacturing workers in favor of more employment in the service sector (Kander 2005). As long ago as the 1960s Baumol and Bowen (1965), Kaldor (1966), and Baumol (1967) were suggesting that "a transfer of resources from manufacturing to services may provide a structural change burden" (Szirmai and Verspagen 2015: 47). More recently, technological progress has accelerated greatly, and use of robotics is suggesting that we will see a growth in unemployment in many sectors. At the same time, financialization of the economy is creating strong dependencies on the financial sector and political economists are predicting a negative impact of financialization on labor productivity. It is suggested that this will result from financial managers and financial corporations prioritizing maximization of their bonuses, shareholder dividends, and financial compensation at the expense of productive investments (Lazonick and O’Sullivan 2000; Palley 2012; Lavoie 2014). This in turn will result in the squandering of their assets on financial speculation and short-term strategies rather exploitation of their financial resources for real expansion, innovation activity, job creation, and increased labor productivity. There is a danger that more flexible labor markets and lack of job protection will threaten "the integrity of employment and social protection regimes", especially in Europe and other advanced economic and industrial relations systems (Prosser 2014: 359). This threat to the integrity of employment will be caused by forced job relocation, and the weakening of labor bargaining power and trade unions in the context of globalization, vis-a-vis capital.

The aim of this Special Issue is to discuss and examine issues in different country contexts based on initial specialization, path dependency, and national institutions. Structural changes have different impacts and outcomes in the context of Eastern versus Western European countries due to their distinct technology and institutional coevolutions which have shaped their dynamics. The level of welfare and the institutions 
and policies governing the variety of capitalism and welfare policy will affect these processes. For instance, some continental European countries have mostly avoided premature de-industrialization and have continued to invest in their manufacturing and capital-intensive sectors rather than in services and finance. The transition observed in the Scandinavian countries towards a service sector dominated by employment in public administration and high-quality social services is resulting in increased productivity and wages. However, other countries have experienced de-industrialization and greater financialization and reliance on robotics alongside an ecological transition. Yet other countries have moved towards an emphasis on low skilled manufacturing and low skilled services sub-sectors which provide low productivity gains and low wages and may or may not integrate environmental concerns. Although the list of changes outlined above is not exhaustive, it provides opportunities for analyses, comparative studies, and empirical reflections, and suggests new theories.

Finally, climate change and sustainability issues impose constraints on the manufacturing industries which tend to be the most polluting sector. Rules, institutions, and appropriate governance are needed to create incentives and promote coordination among agents to achieve sustainable development and supply of decent jobs. Sustainability should be understood in terms of both environmental and social sustainability, and should reduce inequality and poverty and macroeconomic sustainability (or stability). It should be aimed at avoiding booms and boosts and financial euphoria and panics. In the area of consumption, research tends to be dominated by neoclassical economic models of sustainable consumption which represent consumers as substantively rational individuals who make deliberate and autonomous decisions which maximize their individual utility and are based on stable and exogenous preferences and perfect information. However, there is a strand of interdisciplinary literature which includes work in sociology, behavioral economics, evolutionary economics, psychology, and anthropology that is offering some new insights to explain sustainable behavior and the structural changes required for its achievement (Axsen and Kurani 2012; Cordes and Schwesinger 2014; Babutsidze and Chai 2018). Changing patterns of consumption depend as much on the economic values of the different consumers groups as on the capability of these groups to convey their values and influence new consumers. This highlights the need for more learning about sustainable consumption and its impact at both the macro and micro levels (Witt 2017). Veblen's (1899) analysis of the evolution of demand and consumption was further developed by Witt (e.g. Witt 2003, 2008; and see Lazaric et al. in this issue). An evolutionary economics view of consumption and demand emphasizes preferences and values which are typical of evolutionary research responding to contemporary problems (e.g. Buensdorf and Cordes 2008; Cordes and Schwesinger 2014; Cordes 2019). This line of work includes interdisciplinary and what has been called naturalistic research for instance on learning and the transmission of new behaviors such as in consumption of "green" products. This strand of work also shows the pertinence of environmental issues and suggest that the environment is likely to become a pillar of evolutionary-institutional approaches alongside innovation and consumption (e.g. Maréchal and Lazaric 2010; Brouillat and Oltra 2012). In the case of innovation, the long-standing absence of critiques of innovation along with the failure to link innovation to social inclusiveness and ecological sustainability, and the reluctance to consider innovation in terms of governance should be taken seriously since these aspects will shape structural change (e.g. Metcalfe et al. 2005, Gifford and McKelvey 2019; Savona and Ciarli 2019). 
The papers in this Special Issue discuss the sources of structural change from three perspectives.

The first explores the discussion around the complementarity between Keynes and Schumpeter. Pariboni and Tridico's article explores the famous Baumol cost disease which describes productivity slowdown and capital accumulation. In line with SylosLabini (1962), Pariboni and Tridico use panel data for 25 European countries and show that the increase in service activities and the transfer of resources from manufacturing to services may result in a structural change burden which leaves little room for productivity gains and/or increased labor productivity. This change process affects both the structures and the international division of labor. If Schumpeterian dynamics is important for generating innovation, accelerating growth and productivity, fiscal policies will be required to stimulate demand. Keynesian dynamics is a natural driver of Schumpeterian dynamics and may correct some negative externalities linked to these structural changes and creative destruction.

The article by Saviotti et al. discusses the nature and complexity of this structural change. They suggest that structural change can be a mechanism which enables continuing growth over the long term based on the hypothesis of increasing returns (Young 1928). In this scenario, structural change depends on an efficiency-creativity trade off. Efficiency applies to existing processes and works to reduce the amount of output to produce a qualitative constant output. Creativity results in new goods and services which change the economic structure of the system. Both efficiency and creativity are required to drive changes to the structure of economic systems. The nature of these changes will depend on the combination of low quality inter-sectoral diversification and high quality inter and intra sectoral diversification.

The paper by Lazaric et al. focuses on the nature, content, and main determinants of sustainable consumption in the context of France. Their empirical findings help to define sustainable consumption and identify some meso and microlevel indicators. They employ a cluster methodology which incorporates the range from the "highest" to the "lowest" levels of sustainable consumption, to show how environmental values and social influences diffuse among consumers. While their results reveal significant inequalities (based on age, gender, income, localization, etc.) related to sustainable consumption, their empirical findings show that sustainable consumption is "learned" through a process which involves peer pressure and local interactions that provide opportunities to learn from those closest to you (i.e. friends, family, colleagues). In other words, small networks can have a huge impact on sustainable consumption and reinforce pre-existing paths and prior green preferences. This local path dependency and local interactions demonstrate also the difficulties related to changing consumption patterns and the need for policy to reduce consumption inequalities and enable inclusiveness and equal access to allow citizens to learn about sustainability and green products and practices.

The second perspective refers to the impact of financialization. Imami et al.'s paper discusses the changes to informal financial systems following the collapse of the socialist system. These informal systems include savings and credit schema which are very important in many countries especially socialist countries where access to loans is scarce. Lack of private banks and restrictions on loans from state banks results in use of informal finance to meet household needs. This applied during the socialist era where any deviation from the legal and ideological frame was punishable by the state. 
The transition and post-socialist period have allowed individual mobility and increased job insecurity but have also increased citizens' distrust generating progressive abandonment of this ancient monetary tool.

The article by Perillo and Battiston adopts a different view to explain the dramatic growth of the financial sector in Western countries. The financialization of the economy is based on (1) provision of credit and financial services to the economy and to households, and (2) the striking growth in asset management activities, and in profits. Perillo and Battiston discuss the change to the established idea that financialization was good for the economy, and economic growth following the 2007-2008 crisis and the resulting recession which has increased inequality as highlighted by Jacobs and Mazzucato (2016). Perillo and Battiston's empirical analysis highlights the implications of unconventional financial tools in this case the quantitative easing $(\mathrm{QE})$ implemented by the European Central Bank and its effect on the economy and on banks' borrowing behavior. The authors examine the impact of QE for creating additional resources for the real economy and its implications for financialization (intra financial exposures among financial actors).

The third perspective explores the impacts of these structural changes on diverse country clusters. Deleidi et al. use nine selected countries over the period 1970-2015 to illustrate these trends. They show that the stagnation in labor productivity is explained by a small within-sector increase and a structural change towards services i.e. the trend towards tertiarization. They assess the weight of this structural change within and across sectors, and the weight on overall productivity dynamics. They employ the KaldorVerdoorn law to test the impact of demand factors on within productivity growth, and assess the small role of the tertiarization in the period 1999-2015, and the role of demand growth for determining productivity dynamics in manufacturing and the private sector.

The weak demand dynamics following the 2008 crisis contributed to productivity stagnation especially in large economies and countries with large manufacturing sectors.

Gräber et al.'s article was awarded the EAEPE Kapp Prize in 2020 based on its originality and the quality of its empirical findings. It sympathetically combines postKeynesian insights with the notion of path dependence to illustrate the diverse and distinct ways that countries respond to the openness shock caused by European integration. They identify four clusters of countries - core countries, periphery countries, Eastern European catchup countries, and financial hubs. They demonstrate the uneven distribution of technological capabilities which explains the core: periphery duality, and more generally show the relationship between positive change and product complexity and the importance of accumulating technological capabilities. Given that the accumulation of these capabilities is a path dependent process, in the absence of policy interventions these trajectories become self-reinforcing over time. Policy should be implemented to support greater convergence within Europe and the establishment of institutions to achieve a better balance between the leaders and the laggards.

Angelini et al.'s article investigates this issue through the technological patterns followed before and after the 2008 crisis by four Southern countries (Italy, Spain, Greece and Portugal) and three Eastern European countries (Poland, Hungary, Bulgaria) compared to the UK. Their empirical findings demonstrate that the Eastern European countries have not succumbed to de-industrialization and are performing better 
than the Southern countries. They provide empirical evidence that Poland and Portugal were closer to the UK in terms of technology ratio and observe that the deindustrialization process accelerator in the Southern countries occurred after the 2008 crisis and that the transition to services had already taken place.

The final paper in this Special Issue is by Heise and Pusch. It scrutinizes the impact of a minimum wage in Germany based on observation of two groups of firms affected (group A) by the minimum wage or not (group B). Group B firms pay above the minimum wage level. Heise and Pusch's results show a very low overall employment loss in sector A and a small shift from low to higher wage industries (from sector A to sector B), and more generally show that the effect of a minimum wage is negligible and does not promote contractionary monetary reactions. The introduction of a binding minimum wage which caused a small shift from sector A to sector B resulted in an overall drop of $0.1 \%$ in jobs and a fall also in the number of "mini jobs", and has resulted in the need for a re-regulation of industrial relations in Germany to support demand.

\section{References}

Axsen J, Kurani KS (2012) Social influence, consumer behavior, and low-carbon energy transitions. Annu Rev Environ Resour 37:311-340

Ayres RU, van den Bergh J (2005) A theory of economic growth with material/energy resources and dematerialization: Interaction of three growth mechanisms. Ecol Econ 55(1):96-118

Babutsidze Z, Chai A (2018) Look at me saving the planet! The imitation of visible green behavior and its impact on the climate value-action gap. Ecol Econ 146:290-303

Baumol WJ (1967) Macroeconomics of unbalanced growth. Am Econ Rev 51:415-426

Baumol WJ, Bowen WG (1965) On the performing arts: The anatomy of their economic problems. Am Econ Rev 55:495-502

Brouillat E, Oltra V (2012) Dynamic efficiency of extended producer responsibility instruments in a simulation model of industrial dynamics. Ind Corp Change 21(4):971-1009

Buensdorf G, Cordes C (2008) Can sustainable consumption be learned? A model of cultural evolution. Ecol Econ 67(4):646-657

Cézanne C, Lorenz EH, Saglietto L (2020) Exploring the economic and social impacts of Industry 4.0. Rev d'Econ Ind 169:11-35

Ciarli T, Savona M (2019) Modelling the evolution of economic structure and climate change: a review. Ecol Econ 158:51-64

Cordes C (2019) The promises of a naturalistic approach: how cultural evolution theory can inform (evolutionary) economics. J Evol Econ 29:1241-1262

Cordes C, Schwesinger G (2014) Technological diffusion and preference learning in the world of Homo sustinens: The challenges for politics. Ecol Econ 97(C):191-200

Dachs B, Kinkel S, Jaeger A (2019) Bringing it all back home? Back shoring of manufacturing activities and the adoption of Industry 4.0 technologies. J World Bus 54(6):101-117

Dosi G, Fagiolo G, Roventini MC (2010) Schumpeter meeting Keynes: A policy-friendly model of endogenous growth and business cycles. J Econ Dyn Control 34(9):1748-1767

Dosi G, Pereira MC, Roventini A, Virgillito ME (2019) What if supply-side policies are not enough? The perverse interaction of flexibility and austerity. J Econ Behav Organ 162:360-388

Gifford E, McKelvey M (2019) Knowledge-intensive entrepreneurship and S3: conceptualizing strategies for sustainability. Sustainability 11(18):4824

Jacobs M, Mazzucato M (eds) (2016) Rethinking capitalism: Economics and policy for sustainable and inclusive growth. Wiley/Political Quarterly,\&nbsp;Hoboken

Kaldor N (1966) Causes of the slow rate of economic growth in the United Kingdom. Cambridge University Press, London

Kander A (2005) Baumol's disease and dematerialization of the economy. Ecol Econ 55(1):119-130

Keynes JM (1926) The end of laissez-faire. Prometheus Books, London 
Lavoie M (2014) Post-keynesian economics: new foundations. Edward Elgar, Cheltenham

Lazonick W, O’Sullivan M (2000) Maximizing shareholder value: a new ideology for corporate governance. Econ Soc 29(1):13-35

Maréchal K, Lazaric N (2010) Overcoming inertia: insights from evolutionary economics into improved energy and climate policy. Clim Policy 10(1):103-119

Mazzucato M, Cimoli M, Dosi G et al (2015) Which industrial policy does Europe need? Intereconomics 50: $120-155$

Metcalfe JS, James A, Mina A (2005) Emergent innovation systems and the delivery of clinical services: The case of intra-ocular lenses. Res Policy 34(9):1283-1304

Palley T, I., (2012) From financial crisis to stagnation: the destruction of shared prosperity. Cambridge University Press, Cambridge

Prosser T (2014) Financialization and the reform of European industrial relations systems. Eur J Ind Relat 20(4):351-365

Savona M, Ciarli T (2019) Structural changes and sustainability. A selected review of the empirical evidence. Ecol Econ 159:244-260

Sylos-Labini P (1962) Oligopoly and technical progress. Harvard University Press, Cambridge

Szalavetz A (2019) Industry 4.0 and capability development in manufacturing subsidiaries. Technol Forecast Soc Chang 145:384-395

Szirmai A, Verspagen B (2015) Manufacturing and economic growth in developing countries, 1950-2005. Struct Chang Econ Dyn 34(3):46-59

Veblen T (1899) The theory of the leisure class - An economic study of institutions. Macmillan (eds), US

Witt U (2003) The evolving economy: essays on the evolutionary approach to economics. Edward Elgar, Cheltenham

Witt U (2008) What is specific about evolutionary economics? J Evol Econ 18(5):547-575

Witt U (2017) The evolution of consumption and its welfare effects. J Evol Econ 27:273-293

Young AA (1928) Increasing returns and economic progress. Econ J 38(152):527-542

Publisher's note Springer Nature remains neutral with regard to jurisdictional claims in published maps and institutional affiliations. 